\title{
Correction to: Fertilizing behavior of extract of organomineral-activated biochar: low-dose foliar application for promoting lettuce growth
}

\author{
Abhay Kumar 1,2,3, Stephen Joseph ${ }^{4,5,6}$, Ellen R. Graber', Sara Taherymoosavi ${ }^{4}$, David R. G. Mitchell? \\ Paul Munroe ${ }^{4}$, Ludmila Tsechansky' ${ }^{1}$, Ove Lerdahl², Walter Aker ${ }^{2}$ and Mona Sæb $\varnothing^{3^{*}}$ (1)
}

\section{Correction to: Chem Biol Technol Agric (2021) 8:21} https://doi.org/10.1186/s40538-021-00222-x

Following publication of the original article [1], the authors identified an error in the author name of Sara Taherymoosavi.

The incorrect author name is: Sara Taherysoosavi.

The correct author name is: Sara Taherymoosavi.

The original article [1] has been corrected.

\author{
Reference \\ 1. Kumar A, Joseph S, Graber ER, Taherymoosavi S, Mitchell DRG, Munroe P, \\ Tsechansky L, Lerdahl O, Aker W, Sæbø M. Fertilizing behavior of extract of \\ organomineral-activated biochar: low-dose foliar application for promot- \\ ing lettuce growth. Chem Biol Technol Agric. 2021;8:21. https://doi.org/ \\ 10.1186/s40538-021-00222-x.
}

\section{Publisher's Note}

Springer Nature remains neutral with regard to jurisdictional claims in published maps and institutional affiliations.

\begin{abstract}
Author details
'Department of Soil Chemistry, Plant Nutrition and Microbiology, Institute of Soil, Water and Environmental Sciences Agricultural Research Organization, Volcani Center, 7505101 Rishon LeZion, Israel. ${ }^{2}$ Standard Bio, Televegen 2, 3802 Bø i Telemark, Norway. ${ }^{3}$ Department of Natural Sciences and Environmental Health, University of South-Eastern Norway, Gullbringvegen 36, 3800 Bø i Telemark, Norway. ${ }^{4}$ School of Materials Science and Engineering, University of NSW, Sydney, NSW 2052, Australia. Institute of Resource, Ecosystem and Environment of Agriculture, Nanjing Agricultural University, Nanjing 210095, Jiangsu, China. ${ }^{6}$ ISEM and School of Physics, University of Wollongong, Wollongong, NSW 2522, Australia. ${ }^{7}$ Electron Microscopy Centre, AlIM Building, Innovation Campus, University of Wollongong, Squires Way, North Wollongong, NSW 2517, Australia.
\end{abstract}

Published online: 01 July 2021

\footnotetext{
*Correspondence: mona.sabo@usn.no

${ }^{3}$ Department of Natural Sciences and Environmental Health, University of South-Eastern Norway, Gullbringvegen 36, 3800 Bø i Telemark, Norway Full list of author information is available at the end of the article
} in this article are included in the article's Creative Commons licence, unless indicated otherwise in a credit line to the material. If material is not included in the article's Creative Commons licence and your intended use is not permitted by statutory regulation or exceeds the permitted use, you will need to obtain permission directly from the copyright holder. To view a copy of this licence, visit http://creativeco mmons.org/licenses/by/4.0/. The Creative Commons Public Domain Dedication waiver (http://creativecommons.org/publicdomain/ zero/1.0/) applies to the data made available in this article, unless otherwise stated in a credit line to the data. 